\title{
Kiedy korekcja manualna zwiększa dokładność rejestracji obrazu podczas pozycjonowania pacjentów z rakiem prostaty?
}

\author{
When manual correction increases the accuracy of the image \\ registration during positioning patients with prostate cancer?
}

\author{
Tomasz Piotrowski ${ }^{1,2}$, Agata Jodda ${ }^{2}$, Iwona Goncerzewicz ${ }^{1}$, \\ Bartosz Bąk ${ }^{1,3}, K_{r z y s z t o f ~ K a c z m a r e k}{ }^{3}$
}

\begin{abstract}
${ }^{1}$ Katedra i Zakład Elektroradiologii, Uniwersytet Medyczny, Poznań, Polska ${ }^{2}$ Zakład Fizyki Medycznej, Wielkopolskie Centrum Onkologii, Poznań, Polska ${ }^{3}$ Zakład Radioterapii 2, Wielkopolskie Centrum Onkologii, Poznań, Polska
\end{abstract}

\section{Streszczenie}

Podczas pozycjonowania, całkowite przesunięcie ciała pacjenta w którejkolwiek z osi jest sumą przesunięć uzyskanych w wyniku korekcji automatycznej (program komputerowy) i manualnej, zależnej od subiektywnej oceny obserwatora.

Celem badania było określenie progu dla korekcji manualnej, powyżej którego, uwzględnienie jej w sposób istotny wpływa na całkowite przesunięcie ciała pacjenta podczas radioterapii raka stercza.

W badaniu wykorzystano dane obrazowe 60 pacjentów z rakiem stercza leczonych na aparacie tomoterapeutycznym w latach 2012-2015. Codzienne obrazowanie MVCT obejmowało obszar tarczowy (prostata lub prostata wraz z pęcherzykami nasiennymi) powiększony w osi długiej o $10 \mathrm{~mm} \mathrm{z} \mathrm{każdej} \mathrm{strony.}$ Każde dzienne MVCT zostało nałożone na obrazy z planowania leczenia (kVCT) pięciokrotnie, przez pięciu niezależnych obserwatorów. Korekty manualne uzyskane przez obserwatorów zostały uśrednione dla każdej frakcji, dla każdego pacjenta.

Korekcja manualna w sposób istotny wpływa na całkowite przesunięcie ciała pacjenta gdy jej wartość bezwzględna jest większa niż $1 \mathrm{~mm}$. Mniejsze wartości korekcji manualnej mieszczą się w wartości błędu subiektywnej oceny obserwatora i nie powinny być uwzględniane podczas pozycjonowania ciała pacjenta. Wartości korekcji manualnej ściśle korelują z wartościami korekcji automatycznej. Korekcja manualna powinna być uwzględniana gdy bezwzględne wartości korekcji automatycznej są większe od 2 mm.

Adres do korespondencji

dr hab. Tomasz Piotrowski

Zakład Fizyki Medycznej

Wielkopolskie Centrum Onkologii, ul. Garbary 15, 61-866 Poznań, Polska

Telefon. +48618850763; Fax.+48618850551

e-mail: tomasz.piotrowski@wco.pl 


\begin{abstract}
During the positioning, the total shift in each of the directions along the $\mathrm{x}, \mathrm{y}$ or $\mathrm{z}$-axis is a sum of shifts resulting from automatic registration and manual correction.

The aim of this study was to find the level of manual correction, above which the use of manual correction has a significant impact on total shifts of the patient's body during radiotherapy of prostate cancer.

The study based on the image guidance data gathered from 60 consecutive patients with prostate cancer treated on helical tomotherapy between 2012 and 2015. Daily MVCT imaging covered the whole irradiated region (prostate alone or prostate and seminal vesicles) expanded by $10 \mathrm{~mm}$ in the cranio-caudal direction. The MVCT images were re-registered to corresponding planning kVCT images fivefold, by five independent observers. The manual corrections established by observers were averaged for each fraction and for every patient, respectively.

The manual corrections significantly affect the accuracy of the registrations when the absolute shift is higher than $1 \mathrm{~mm}$. Lower shifts from manual corrections are burdened by the error resulting from interobserver variability and should not be applied to the total shift during registration process. Shifts from manual corrections correlated with the shifts from automatic registration. The manual corrections should be taken into account when shifts from automatic registration are higher than $2 \mathrm{~mm}$.
\end{abstract}

Słowa kluczowe: radioterapia raka stercza; korekcja manualna; IGRT; fuzja obrazów

Keywords: prostate cancer radiotherapy; manual correction; IGRT; image registration

\title{
Wstęp
}

Jedną z najbardziej zaawansowanych metod weryfikacji obrazowych w radioterapii umożliwiającą ocenę zgodności na podstawie tkanek miękkich jest metoda MVCT dostępna na aparacie tomoterapeutycznym (MVCT; ang. Mega Voltage Computed Tomography) [1,2]. Obrazy MVCT, podobnie jak obrazy utworzone metodą kilowoltowej wiązki stożkowej (CBCT; ang. Cone Beam Computed Tomography) na konwencjonalnych aparatach terapeutycznych [3,4], przedstawiają anatomię pacjenta $\mathrm{w}$ trakcie kursu radioterapii, która podczas weryfikacji obrazowej porównywana jest z anatomią pacjenta z przed rozpoczęcia radioterapii, zobrazowaną na tomografie komputerowym (kVCT; kilo Voltage Computed Tomography). Uściślając, porównanie to odbywa się poprzez nałożenie a następnie dopasowanie obrazu MVCT do obrazu kVCT. Operacja ta realizowana jest przed podaniem dawki frakcyjnej przy użyciu dedykowanego oprogramowania komputerowego zainstalowanego na stacjach komputerowych w sterowni aparatu terapeutycznego. Uzyskane w ten sposób wartości przesunięć obrazu MVCT względem obrazu kVCT wykorzystywane są podczas pozycjonowania pacjenta, tak aby uzyskać jak największą zgodność pomiędzy aktualną pozycją pacjenta na aparacie terapeutycznym a pozycją, w której był on ułożony podczas obrazowania kVCT (obrazy na podstawie których utworzono plan leczenia) [5,6].

Proces nałożenia i dopasowania obrazów określany jest mianem rejestracji obrazów i odbywa się zazwyczaj dwustopniowo. W pierwszym etapie wykorzystuje się metody automatyczne (AR; automatic registration) realizowane w oparciu o zaimplementowane w oprogramowaniu algorytmy rejestracji obrazu. Uzyskane w ten sposób nałożenie można skorygować ręcznie. Korekcja manualna (MC; manual correction) wykonywana jest przez obserwatora poprzez krokowe (co o,1 mm) przesuwanie obrazu MVCT względem obrazu kVCT $[7,8]$.

O ile rejestracja automatyczna jest procesem w pełni skomputeryzowanym i powtarzalnym to korekcja manualna ściśle zależy od subiektywnej oceny obserwatora. Stąd też istotnym wydaje się określenie minimalnej wartości dla korekcji manualnej, dla której decyzje podjęte przez niezależnych obserwatorów są zgodne i w efekcie, w sposób istotny prowadzą do poprawy pozycji pacjenta w trakcie kursu radioterapii. 


\section{Cel}

Celem pracy była ocena uzyskanych w trakcie weryfikacji obrazowej wartości przesunięć korygujących ułożenie pacjenta podczas radioterapii raka stercza.

Cele szczegółowe obejmowały odpowiednio: (i) określenie progu dla korekcji manualnej, powyżej którego, uwzględnienie jej w sposób istotny wpływa na całkowite przesunięcie ciała pacjenta podczas radioterapii raka stercza; (ii) określenie wartości błędu subiektywnej oceny obserwatora jakim obarczona jest korekcja manualna; (iii) zbadanie potencjalnych zależności pomiędzy wartościami korekcji automatycznej i manualnej.

\section{Material i metoda}

W badaniu wykorzystano dane obrazowe 60 pacjentów z rakiem stercza leczonych na aparacie tomoterapeutycznym w latach 2012-2015. Kliniczny obszar napromieniania (CTV; ang. Clinical Target Volume) ograniczony był do prostaty (44 pacjentów) lub do prostaty wraz z podstawą pęcherzyków nasiennych (16 pacjentów). W każdym z przypadków CTV powiększony był o margines 10 mm, z wyjątkiem strony odbytnicy gdzie dodawano margines $7 \mathrm{~mm}$. Tak określony obszar tarczowy (PTV; ang. Planning Target Volume) napromieniono dawką całkowitą $72 \mathrm{~Gy}$, podaną w 36 dziennych frakcjach napromieniania.

W celu utworzenia planów leczenia wykorzystano komputerowy system planowania leczenia TomoTherapy HiArt w wersji 4.2 (Accuray Inc., Sunnyvale, CA, USA). Szerokość pola wynosiła $1 \mathrm{~cm}$ (51 pacjentów) lub 2.5 cm (9 pacjentów), parametr skoku obrotu głowicy wokół ciała pacjenta (ang. pitch) wynosił zawsze 0.287 oraz współczynnik modulacji (ang. modulation factor) mieścił się w zakresie od 2.3 do 2.7 (modalna wynosiła 2.4) [9]. Wszyscy pacjenci leczeni byli w ułożeniu na plecach z unieruchomieniem kolan i stóp (Combifix; CIVCO Radiotherapy, Coralville, IA, USA). Codzienne obrazowanie MVCT obejmowało obszar tarczowy powiększony w osi pionowej o $10 \mathrm{~mm}$ z każdej strony.

W oparciu o zebrane dane obrazowe przeprowadzono badanie retrospektywne w trakcie którego, każde dzienne MVCT zostało nałożone na obrazy z planowania leczenia (kVCT). Procedura rejestracji automatycznej (AR) obrazu MVCT z obrazem kVCT dla każdej frakcji napromieniania została wykonana jednokrotnie w oparciu o tkanki miękkie i struktury kostne (ang. bone and soft tissue technique). Stanowiła ona podstawę do dalszych operacji przeprowadzanych przez pięciu niezależnych obserwatorów, które realizowane były w następujący sposób: (a) ocena AR przez operatora i naniesienie ewentualnych korekcji manualnych (MC); (b) zarchiwizowanie przesunięć uzyskanych dla MC w systemie bazodanowym; (c) wyzerowanie uzyskanych przesunięć do wartości początkowych uzyskanych dla AR.

Wartość przesunięcia całkowitego (TS) określono jako sumę przesunięć uzyskanych w wyniku AR oraz MC. Uzyskane przesunięcia poddano analizie wzdłuż każdej z osi ciała pacjenta: pionowej, strzałkowej i poprzecznej.

W celu zbadania potencjalnej zależności pomiędzy wartościami przesunięć AR i MC przeprowadzono testy korelacyjne metodą Spearmana. Testy te przeprowadzone zostały dla poziomu istotności statystycznej $\alpha=0.05$.

W celu określenia zróżnicowania wartości korekty manualnej zastosowano współczynnik zmienności. Współczynnik zmienności to miara zróżnicowania rozkładu cechy zależna od średniej arytmetycznej liczonej dla bezwzględnych wartości przesunięć uzyskanych dla MC i odchylenia standardowego [10]

$$
\mathrm{W}_{\mathrm{z}}=\frac{\mathrm{SD}}{\overline{\overline{\mathrm{x}}}}, \overline{\overline{\mathrm{x}}} \neq 0
$$

gdzie: $\overline{\bar{x}}$ to średnia arytmetyczna liczona z wartości bezwzględnych przesunięć uzyskanych dla MC a SD to odpowiadające jej odchylenie standardowe.

W przypadku gdy Wz osiąga wartości od o do o.5 zmienność określana jest jako mała, gdy mieści się w przedziale od 0.5 do 1 zmienność określana jest jako umiarkowana oraz jako duża gdy wartość jego jest większa od $1[10,11]$. Należy jednak zauważyć, że średnia $\bar{x}$ liczona jest z wartości bezwzględnych przesunięć więc współczynnik ten gubi informację o dominującym zwrocie („in plus” albo „in minus”) przesunięć uzyskanych dla MC.

Analiza zwrotu dla przesunięć uzyskanych dla MC przeprowadzona została w oparciu o bezwzględny 
współczynnik skośności będący miarą asymetrii rozkładu, który wyrażony jest jako trójkrotność wartości bezwzględnej stosunku różnicy średniej arytmetycznej i mediany do odchylenia standardowego [12,13].

$$
\mathrm{W}_{\mathrm{s}}=3\left|\frac{\tilde{\mathrm{x}}-\mathrm{M}}{\mathrm{SD}}\right|
$$

gdzie: $\widetilde{x}$ jest średnią arytmetyczną przesunięć uzyskanych dla MC, SD to odpowiadające jej odchylenie standardowe a M jest medianą przesunięć.

Warto zauważyć że posłużono się wartością bezwzględną współczynnika skośności, upraszczając tym samym analizę do obserwacji zróżnicowanych od $\mathrm{W}_{\mathrm{s}}$ równego o (brak asymetrii rozkładu równoważny $\mathrm{z}$ brakiem dominującego zwrotu przesunięć) i wartości większych gdzie, im większa wartość $\mathrm{W}_{\mathrm{S}}$ tym większa asymetria [12]. W przypadku gdy różnica między średnią arytmetyczną $\widetilde{\mathrm{x}}$ a medianą przesunięć $\mathrm{M}$ jest dwukrotnością odchylenia standardowego wtedy współczynnik skośności przyjmuje wartość $\mathrm{W}_{\mathrm{s}}=6$. Asymetria rozkładu przesunięć MC uznawana jest za istotną gdy wartość współczynnika skośności jest większa od $6\left(\mathrm{~W}_{\mathrm{S}}>6\right)[12]$.

Aby przybliżyć zagadnienia zmienności i skośności posłużono się ryciną 1, na której przedstawiono zbiór dwudziestu hipotetycznych przesunięć MC cechujący się odpowiednio: (A) dużą zmiennością oraz małą skośnością; (B) dużą zmiennością i dużą skośnością; (C) małą zmiennością i małą skośnością oraz (D) małą zmiennością i dużą skośnością. Zakładając, że każde przesunięcie MC należące do zbioru przedstawionego na rycinie 1 uzyskane jest przez innego, niezależnego obserwatora to uśrednione przesunięcie MC (na rycinie 1 oznaczone czerwoną kropką) istotne jest jedynie dla sytuacji (B) oraz (D).

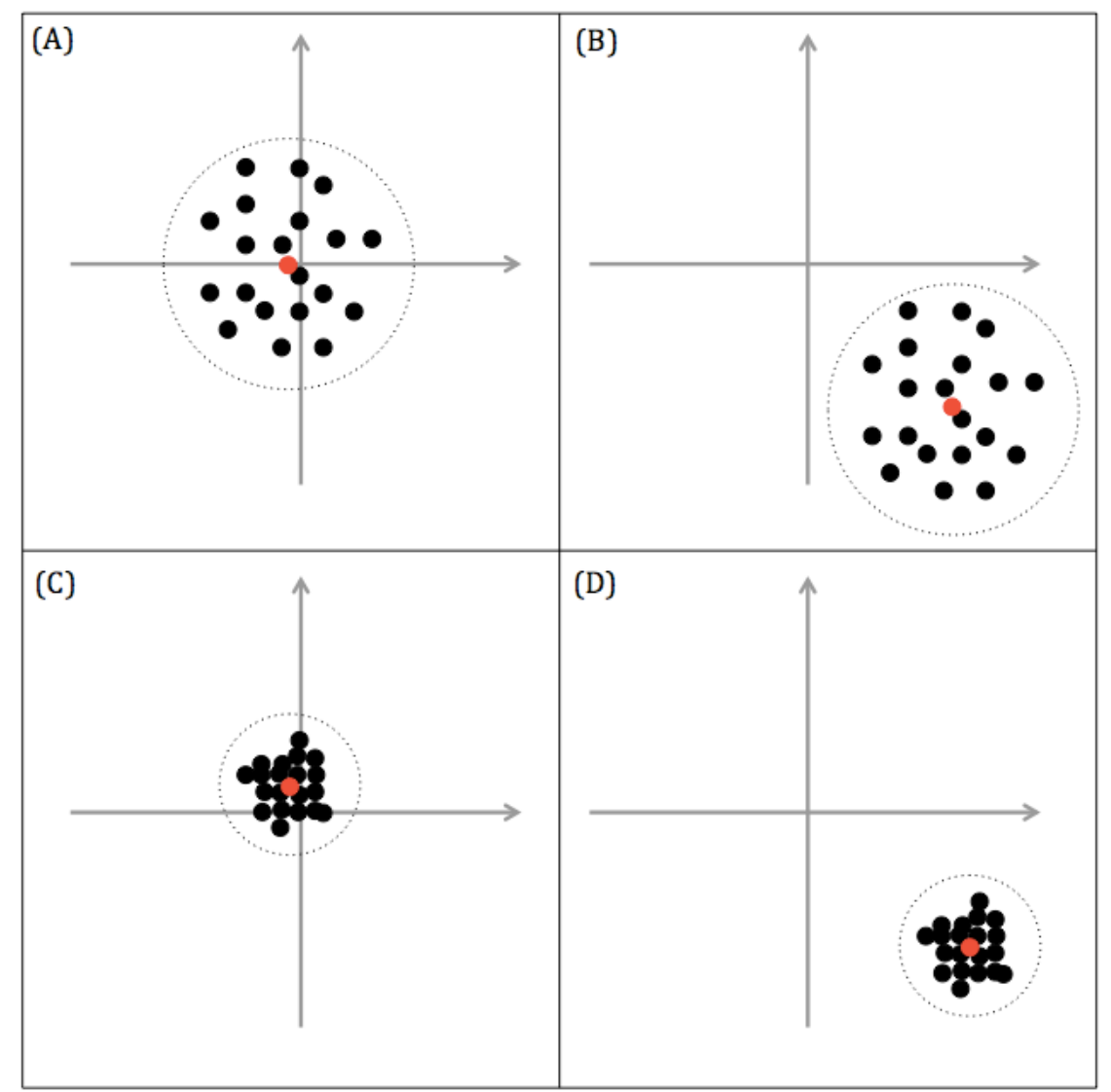

Rycina 1. Schematyczna wizualizacja współczynników zmienności i skośności dla zbioru dwudziestu hipotetycznych przesunięć uzyskanych w wyniku korekcji manualnej (MC) przeprowadzonej przez dwudziestu niezależnych obserwatorów (każde przesunięcie związane z innym obserwatorem) (A) zmienność duża i mała skośność, (B) zmienność duża i duża skośność; (C) zmienność mała i mała skośność oraz (D) zmienność mała i duża skośność. Kolorem czerwonym przedstawiono uśrednione przesunięcie MC. 


\section{Wyniki i omówienie}

W tabeli 1 przedstawiono procent obserwacji przesunięć całkowitych (TS) pogrupowanych w przedziałach milimetrowych, począwszy od przedziału grupującego przesunięcia całkowite od zera do 1 milimetra a skończywszy na przedziale grupującym przesunięcia od 16 milimetrów do 17 milimetrów. Obserwacje przedstawiono dla każdej z osi jak i dla każdego obserwatora uczestniczącego w badaniu. Jak widać w tabeli 1 największa liczba obserwacji kumuluje się w pierwszych czterech przedziałach przesunięć całkowitych. Oznacza to, że zarówno dla każdego z obserwatorów jak i dla każdej z osi ponad 75\% przesunięć całkowitych mieści się w przedziale od zera do 4 milimetrów.

Tabela 1. Rozrzut przesunięć całkowitych [mm] wzdłuż osi poprzecznej, pionowej i strzałkowej uzyskany dla pięciu obserwatorów uczestniczących w badaniu.

\begin{tabular}{|c|c|c|c|c|c|c|c|c|c|c|c|c|c|c|c|}
\hline Obserwator & 1 & 2 & 3 & 4 & 5 & 1 & 2 & 3 & 4 & 5 & 1 & 2 & 3 & 4 & 5 \\
\hline \multirow{2}{*}{$\begin{array}{l}\text { Przesunięcia } \\
\text { całkowite } \\
{[\mathrm{mm}]}\end{array}$} & \multicolumn{15}{|c|}{ Obserwacje [\%] } \\
\hline & \multicolumn{5}{|c|}{ Oś poprzeczna } & \multicolumn{5}{|c|}{ Oś pionowa } & \multicolumn{5}{|c|}{ Oś strzałkowa } \\
\hline$[0,1)$ & 24.5 & 22.9 & 23.4 & 22.3 & 23.4 & 31.5 & 29.4 & 29.9 & 30.3 & 29.5 & 31.7 & 29.7 & 29.2 & 32.0 & 31.4 \\
\hline$[1,2)$ & 21.5 & 23.7 & 22.9 & 23.1 & 21.7 & 26.6 & 27.1 & 26.2 & 27.1 & 26.3 & 30.7 & 27.6 & 27.6 & 29.2 & 30.5 \\
\hline$[2,3)$ & 24.9 & 18.9 & 19.1 & 21.3 & 20.7 & 25.3 & 22.5 & 22.8 & 20.0 & 21.7 & 21.5 & 22.5 & 21.9 & 20.1 & 20.0 \\
\hline$[3,4)$ & 8.6 & 12.7 & 13.3 & 10.9 & 12.3 & 7.7 & 11.5 & 12.4 & 12.1 & 11.4 & 8.6 & 11.3 & 12.1 & 9.6 & 9.3 \\
\hline$[4,5)$ & 4.1 & 4.9 & 4.1 & 5.3 & 4.9 & 2.7 & 3.4 & 2.5 & 3.7 & 4.3 & 1.8 & 3.0 & 3.1 & 3.8 & 3.2 \\
\hline$[5,6)$ & 3.1 & 3.6 & 3.6 & 3.5 & 3.3 & 1.9 & 1.7 & 1.9 & 2.1 & 1.9 & 1.4 & 1.7 & 1.8 & 1.1 & 1.6 \\
\hline$[6,7)$ & 2.9 & 2.9 & 3.0 & 2.7 & 3.3 & 1.1 & 1.8 & 1.5 & 1.2 & 1.3 & 1.1 & 1.3 & 1.3 & 0.9 & 0.4 \\
\hline$[7,8)$ & 2.6 & 2.3 & 2.4 & 2.4 & 2.4 & 1.0 & 0.7 & 0.8 & 1.4 & 1.1 & 1.2 & 0.9 & 0.9 & 1.1 & 1.7 \\
\hline$[8,9)$ & 1.7 & 1.9 & 1.6 & 2.3 & 1.9 & 0.8 & 0.6 & 0.7 & 0.4 & 0.8 & 0.7 & 0.7 & 0.7 & 0.9 & 0.7 \\
\hline$[9,10)$ & 1.6 & 1.5 & 2.1 & 1.7 & 1.5 & 0.5 & 0.7 & 0.5 & 0.7 & 0.5 & 0.3 & 0.3 & 0.3 & 0.5 & 0.5 \\
\hline$[10,11)$ & 1.3 & 1.2 & 1.1 & 1.7 & 1.6 & 0.5 & 0.3 & 0.5 & 0.7 & 0.9 & 0.4 & 0.6 & 0.7 & 0.2 & 0.3 \\
\hline$[11,12)$ & 0.9 & 1.1 & 1.3 & 0.5 & 0.7 & 0.3 & 0.3 & 0.2 & 0.3 & 0.2 & 0.3 & 0.1 & 0.1 & 0.4 & 0.4 \\
\hline$[12,13)$ & 0.9 & 0.9 & 0.5 & 0.6 & 0.7 & & & & 0.1 & 0.1 & 0.1 & 0.1 & 0.1 & 0.1 & 0.0 \\
\hline$[13,14)$ & 0.5 & 0.7 & 0.7 & 0.9 & 0.7 & & & & & & 0.1 & 0.0 & 0.0 & 0.1 & 0.1 \\
\hline$[14,15)$ & 0.5 & 0.5 & 0.5 & 0.3 & 0.5 & & & & & & 0.1 & 0.1 & 0.1 & 0.1 & 0.1 \\
\hline$[15,16)$ & 0.3 & 0.3 & 0.2 & 0.3 & 0.3 & & & & & & 0.1 & 0.1 & 0.1 & & \\
\hline$[16,17]$ & 0.1 & 0.1 & 0.1 & 0.2 & 0.1 & & & & & & & & & & \\
\hline
\end{tabular}

Należy jednak pamiętać że przesunięcie TS jest sumą przesunięć uzyskanych w wyniku rejestracji automatycznej (AR) i korekcji manualnej (MC). W celu zbadania zależności pomiędzy tymi przesunięciami przeprowadzono korelacje metodą Spearmana pomiędzy ich uśrednionymi wartościami, dla każdego z przedziałów przedstawionych w tabeli 1. Jak widać na rycinie 2 istnieje ścisła zależność pomiędzy wartościami przesunięć AR oraz MC dla każdego analizowanego kierunku (osie poprzeczna, pionowa oraz strzałkowa). Wraz ze wzrostem przesunięć AR wzrastają przesunięcia MC. Niemniej jednak należy zauważyć, że przesunięcia MC osiągają względem AR relatywnie niskie wartości. Zakres średnich przesunięć MC dla osi poprzecznej i pionowej mieści się w przedziale od o $\mathrm{mm}$ do $3 \mathrm{~mm}$, dla osi strzałkowej jest on większy i mieści się w przedziale od o $\mathrm{mm}$ do $7 \mathrm{~mm}$. 
Oś poprzeczna

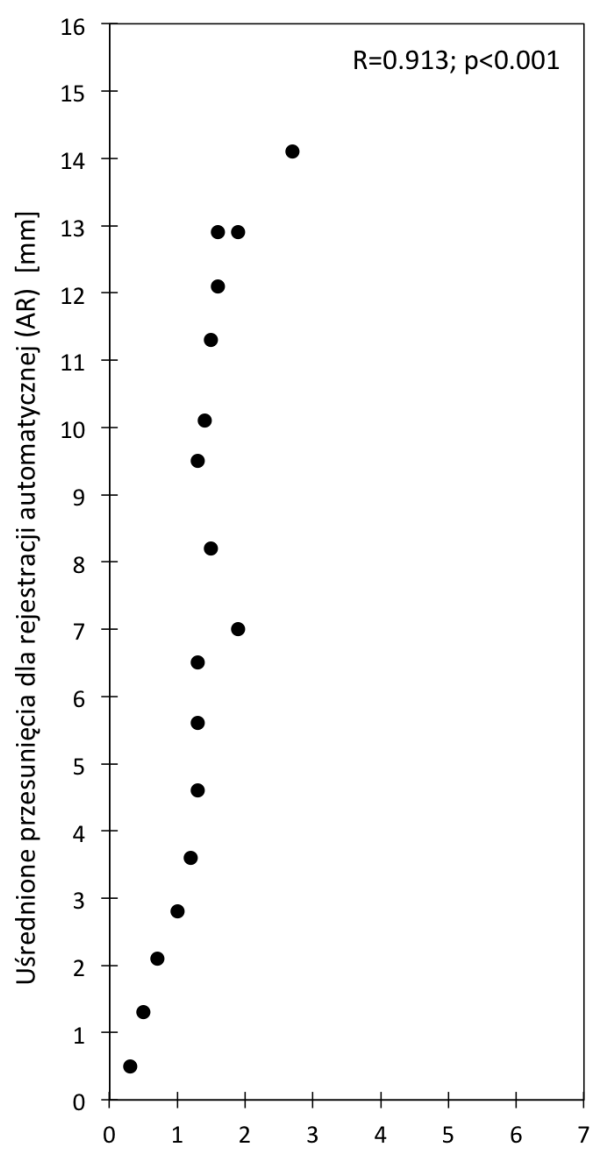

Oś pionowa

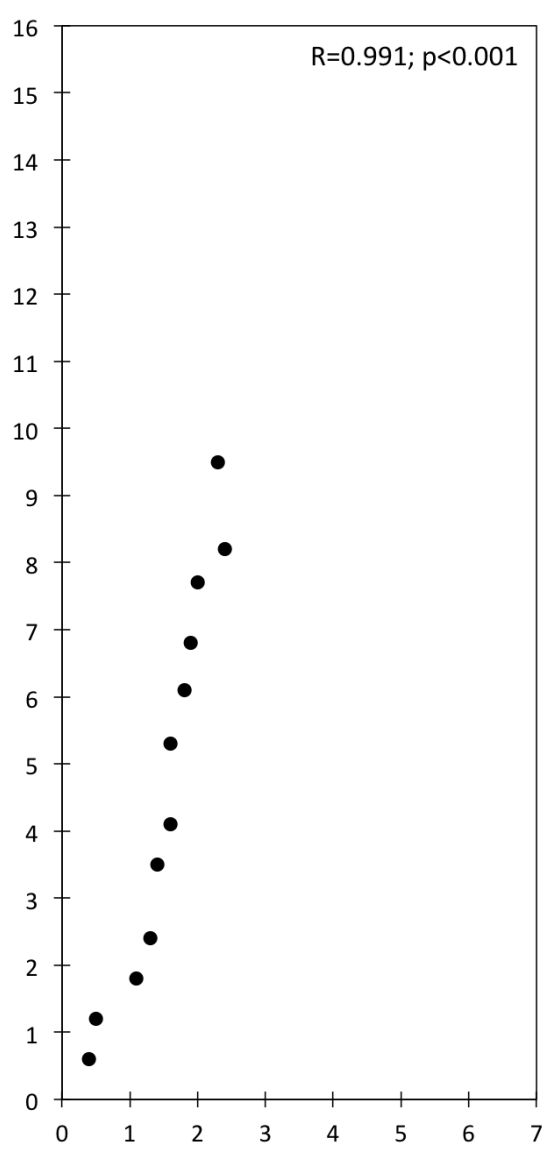

Oś strzałkowa

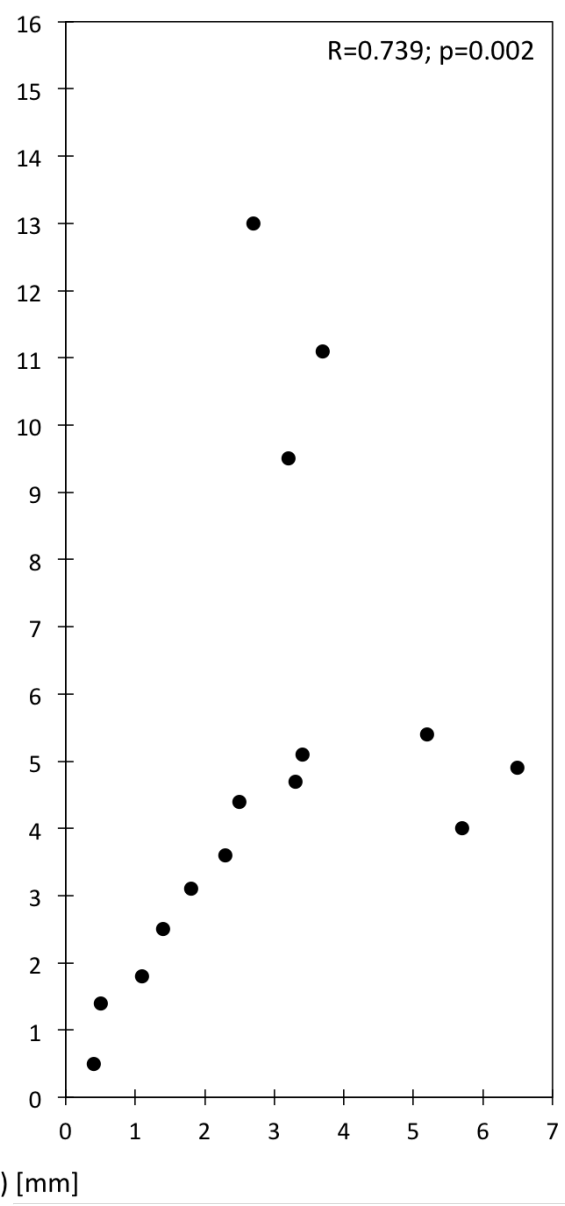

Rycina 2. Korelacja pomiędzy przesunięciami uzyskanymi dla rejestracji automatycznej (AR) i korekcji manualnej (MC) dla osi poprzecznej, pionowej i strzałkowej. Korelacja przeprowadzona metodą Spearmana na poziomie istotności statystycznej $\alpha=0.05$.

Uśrednione przesunięcia MC obliczone zostały w oparciu o wyniki uzyskane przez wszystkich obserwatorów. W celu określenia zróżnicowania wartości korekty manualnej MC dodawanej przez każdego z obserwatorów z osobna przeprowadzono analizę współczynnika zmienności (wzór 1). Jak widać na rycinie 3 wraz z maleniem wartości przesunięcia MC wzrasta współczynnik zmienności (wzrastają rozbieżności pomiędzy wartościami przesunięć MC wyznaczanymi przez różnych obserwatorów). Zgodnie z definicją [10,11] zmienność określana jest jako mała gdy współczynnik zmienności osiąga wartości mieszczące się w przedziale od zera do 0.5. Analizując rycinę 3 można stwierdzić, że małą zmiennością obarczone są przesunięcia MC większe niż $1 \mathrm{~mm}$. Zmienność dla przesunięcia MC mniejszych niż $1 \mathrm{~mm}$ jest umiarkowana lub duża. 

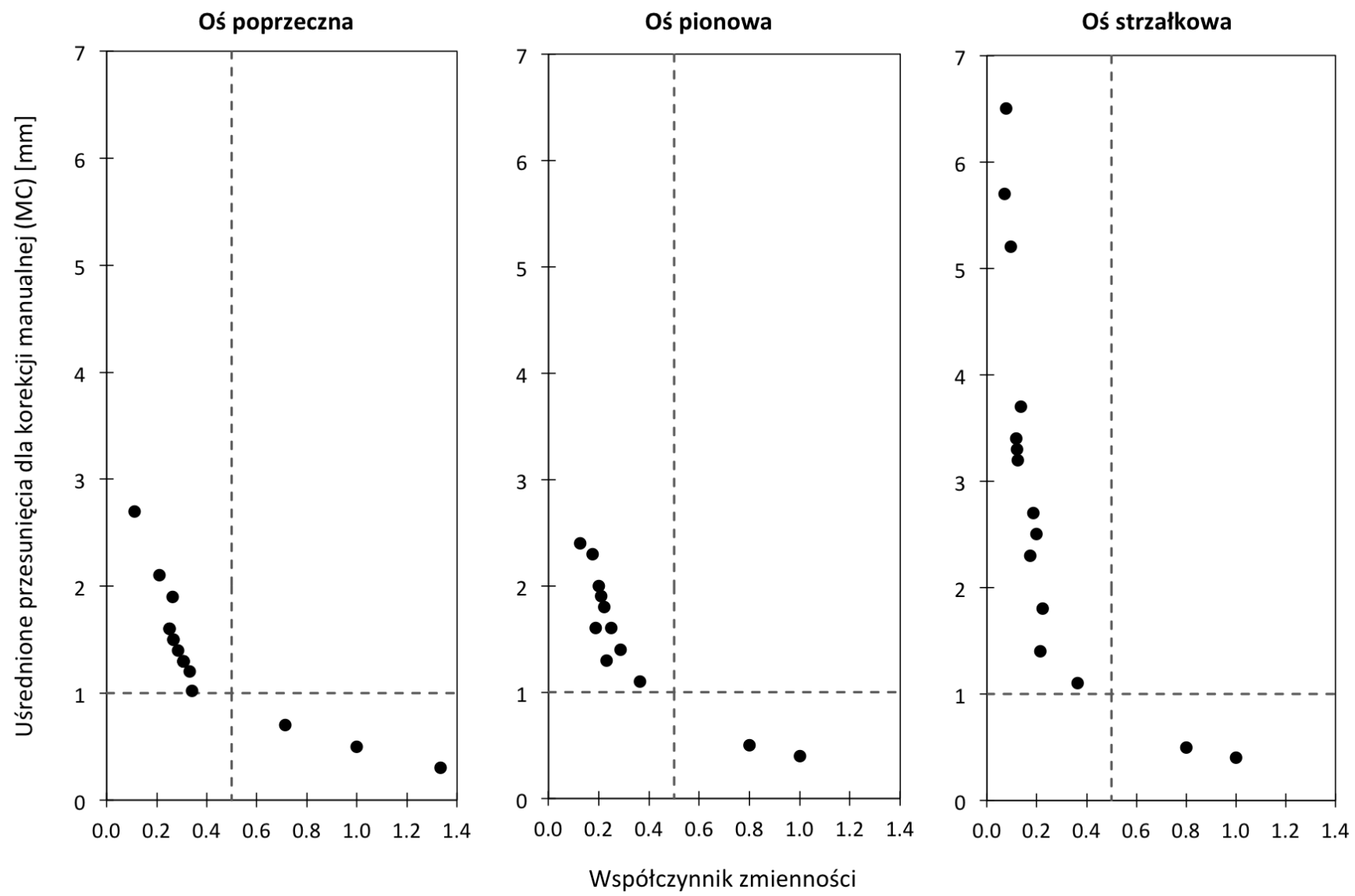

Rycina 3. Zależność pomiędzy uśrednionymi przesunięciami korekcji manualnej (MC) a odpowiadającymi im współczynnikami zmienności. Zmienność określana jest jako: (1) mała, gdy współczynnik zmienności mieści się w przedziale od o do 0.5; (2) umiarkowana gdy współczynnik zmienności mieści się w przedziale od o.5 do 1; (3) duża gdy wartość współczynnika zmienności jest większa od 1. Linie przerywane oznaczają odpowiednio: pionowa - próg odcięcia pomiędzy małą i umiarkowaną zmiennością oraz pozioma - próg odcięcia pomiędzy uśrednionymi przesunięciami MC mniejszymi i większymi niż $1 \mathrm{~mm}$.

Współczynnik zmienności w naszym badaniu wyznaczony był w oparciu o bezwzględne wartości przesunięć MC. Założenie to skutecznie wyeliminowało informacje o zwrocie uzyskiwanych przesunięć MC. Na przykład, przesunięcia MC uzyskane dla tego samego pacjenta, tej samej frakcji napromieniania i tworzące zbiór obserwacji poczynionych przez pięciu niezależnych obserwatorów $\mathrm{A}=\{0.1,-0.3,0.2,-0.4$, -0.1\} przedstawione w postaci bezwzględnej tworzą zbiór $A^{\prime}=\{0.1,0.3,0.2,0.4,0.1\}$. Na podstawie obserwacji zawartych w zbiorze A' nie można uzyskać informacji o dominującym zwrocie, która widoczna jest dla zbioru A. Uśrednione przesunięcia MC o umiarkowanej zmienności (współczynnik zmienności od o.5 do 1) ale o wyraźnym zwrocie należy uznać za istotne. Dlatego też w celu analizy zwrotu przesunięć MC przeprowadzono obliczenia współczynnika skośności będącego miarą asymetrii rozkładu przesunięć MC uzyskanych przez pięciu niezależnych obserwatorów (wzór 2). 

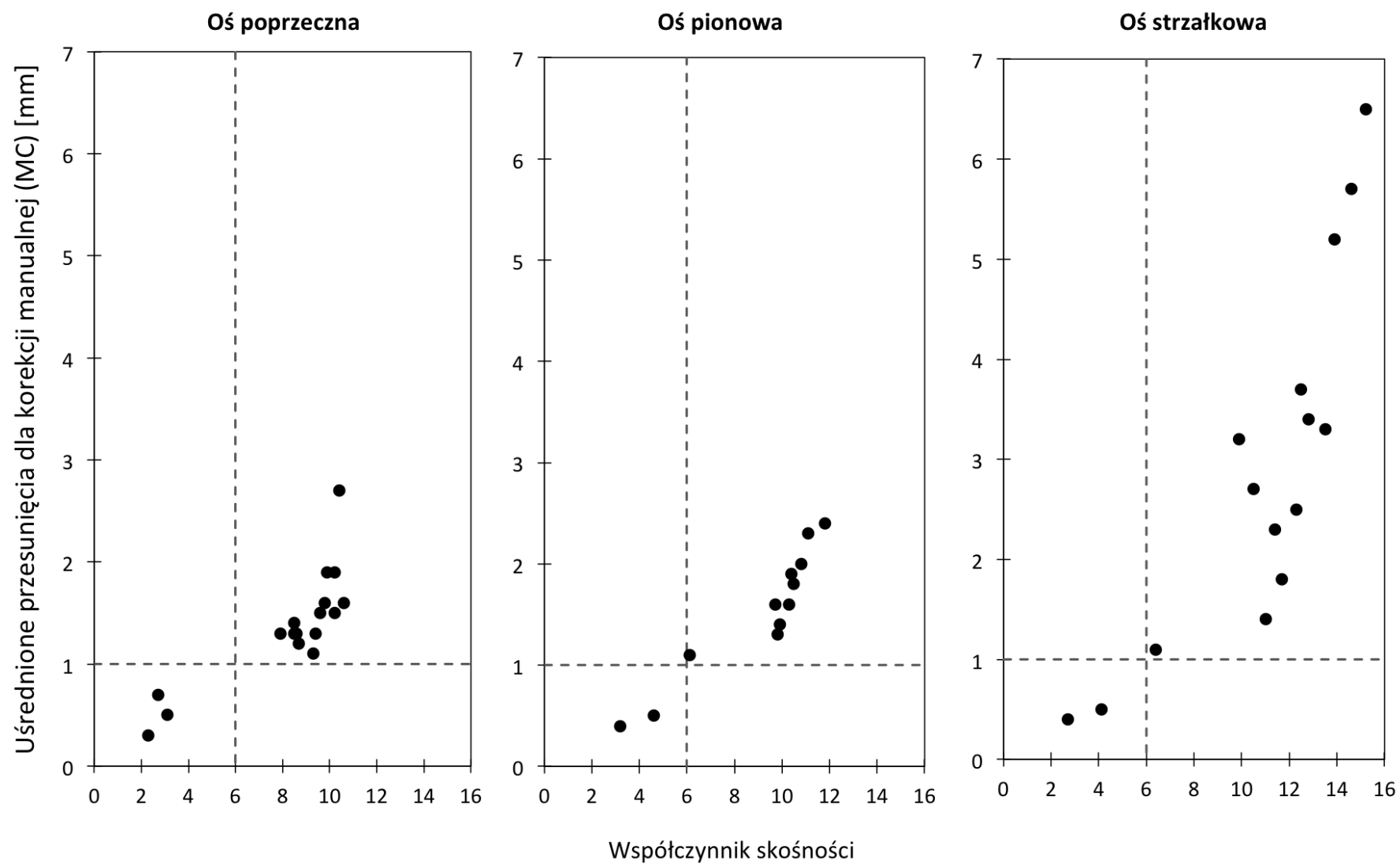

Rycina 4. Zależność pomiędzy uśrednionymi przesunięciami korekcji manualnej (MC) a odpowiadającymi im współczynnikami skośności. Asymetria rozkładu przesunięć $\mathrm{MC}$ uznawana jest za istotną dla $\mathrm{W}_{\mathrm{s}}>6$. Linie przerywane oznaczają odpowiednio: pionowa - próg odcięcia pomiędzy nieistotną i istotną asymetrią rozkładu oraz pozioma - próg odcięcia pomiędzy uśrednionymi przesunięciami MC mniejszymi i większymi niż $1 \mathrm{~mm}$.

Jak widać na rycinie 4, istotną asymetrię rozkładu (WS>6) uzyskano dla uśrednionych przesunięć MC większych niż jeden milimetr. Oznacza to, że zbiory przesunięć zebrane przez pięciu niezależnych obserwatorów dla których uśredniona wartość była mniejsza niż $1 \mathrm{~mm}$ nie cechowały siężadnym dominującym zwrotem, czyli zwrot „in plus” był obserwowany z podobną częstotliwością jak zwrot „in minus”. Z kolei dla uśrednionych przesunięć MC większych niż $1 \mathrm{~mm}$ widoczna była asymetria rozkładu, czyli większość obserwacji dla uśrednionego przesunięcia miała ściśle określony zwrot.

Zarówno analiza współczynnika zmienności jak i skośności wskazuje, że przesunięcia uzyskane w wyniku korekty manualnej, których wartość jest mniejsza od $1 \mathrm{~mm}$ nie wpływają na korekcję całkowitą będącą złożeniem korekt automatycznej i manualnej. Przesunięcia MC większe niż jeden milimetr stanowią istotną komponentę przesunięcia całkowitego. Należy także pamiętać, że przesunięcia MC korelują z przesunięciami AR (rycina 1). Przesunięciom MC równym jeden milimetr odpowiadają dwu milimetrowe przesunięcia AR (rycina 1). Stąd też próby korekt manualnych nie powinny być podejmowanie w sytuacji gdy wartość korekty automatycznej jest mniejsza niż $2 \mathrm{~mm}$.

\section{Wnioski}

Korekcja manualna w sposób istotny wpływa na całkowite przesunięcie ciała pacjenta gdy jej wartość bezwzględna jest większa niż $1 \mathrm{~mm}$. Mniejsze wartości korekcji manualnej mieszczą się w wartości błędu subiektywnej oceny obserwatora i nie powinny być uwzględniane podczas pozycjonowania ciała pacjenta. Wartości korekcji manualnej ściśle korelują z wartościami korekcji automatycznej. Jednomilimetrowej korekcji manualnej odpowiada dwumilimetrowa korekcja automatyczna. Dlatego też korekcja manualna 
powinna być uwzględniana gdy bezwzględne wartości korekcji automatycznej są większe od 2 mm.

\section{Konflikt interesu / Conflict of interest}

Nie występuje / None

\section{Finansowanie / Financial support}

Artykuł został sfinansowany z grantu Wielkopolskiego Centrum Onkologii w Poznaniu, nr 26/2014(85) / This work was supported by the Greater Poland Cancer Centre, grant no 26/2014(85).

\section{Etyka / Ethics}

Treści przedstawione w artykule są zgodne z zasadami Deklaracji Helsińskiej, dyrektywami EU oraz ujednoliconymi wymaganiami dla czasopism biomedycznych.

\section{Piśmiennictwo / References}

[1] Bąk B, Adamska A, Kaźmierska J, Piotrowski T. Nowoczesne metody radioterapii - tomoterapia. Inz Fiz Med 2014;3:333-338.

[2] Piotrowski T, Skórska M, Jodda A, Ryczkowski A, Kaźmierska J, Adamska K, i wsp. Tomotherapy different way of dose delivery in radiotherapy. Wspolcz Onkol 2012;16:16-25.

[3] Martins L, Couto JG, Barbosa B. Use of planar kV vs. CBCT in evaluation of setup errors in oesophagus carcinoma radiotherapy. Rep Pract Oncol Radiother 2016;21:57-62.

[4] Cyra J, Adamczyk M, Milecki P, Jodda A, Piotrowski T. Porównanie dwóch metod weryfikacji geometrycznej podczas radioterapii raka prostaty. Zeszyty Naukowe WCO (Letters in Oncology Science) 2014;11:45-52.

[5] Piotrowski T, Yartsev S, Rodrigues G, Bajon T. Comparative analysis of image guidance in two institutions for prostate cancer patients. Rep Pract Oncol Radiother 2014;19:206-213.

[6] Adamczyk M, Piotrowski T, Adamiak E. Evaluation of combining bony anatomy and soft tissue position correction strategies for IMRT prostate cancer patients. Rep Pract Oncol Radiother 2012;17:104-109.

[7] Piotrowski T, Kaczmarek K, Bajon T, Ryczkowski A, Jodda A, Kaźmierska J. Evaluation of imageguidance strategies for prostate cancer. Technol Cancer Res Treat 2014;13:583-591.

[8] Yeung TPC, Yartsev S, Rodrigues G, Bauman G. Evaluation of image-guidance strategies with helical tomotherapy for localized prostate cancer. J Med Imaging Radiat Oncol 2011;55:220-8.

[9] Piotrowski T, Czajka E, Bak B, Kazmierska J, Skorska M, Ryczkowski A, Adamczyk M, Jodda A. Tomotherapy: Implications on daily workload and scheduling patients based on three years' institutional experience. Technol Cancer Res Treat 2014;13:233-242.

[10] Everitt B. The Cambridge Dictionary of Statistics. Cambridge, UK New York: Cambridge University Press; 1998.

[11] Wawrzynek J. Metody opisu i wnioskowania statystycznego. Wrocław: Wydawnictwo Akademii Ekonomicznej im. Oskara Langego we Wrocławiu; 2007.

[12] Hildebrand DK. Statistical Thinking for Behavioral Scientists. Boston: Duxbury, 1986.

[13] Bowley AL. Elements of Statistics. 4th ed. New York: Charles Scribner; 1920. 